\title{
急性期脳梗塞患者におけるアルガトロバン投与中の症状悪化と投与方法の関連性についての検討
}

\author{
須永登美子, ${ }^{*}, a, b$ 東野真弓, ${ }^{a, b}$ 木村綾沙, ${ }^{c}$ 馬場康彦, ${ }^{d}$ \\ 谷岡利裕, ${ }^{c}$ 渡邊 徹, ${ }^{a, b}$ 佐々木忠徳 $a$
}

\section{Examination of the Relationship between Worse Symptom and Differences Route during Administration of Argatroban in Acute Ischemic Stroke Patients}

\author{
Tomiko Sunaga, ${ }^{*, a, b}$ Mayumi Higashino, ${ }^{a, b}$ Ayasa Kimura, ${ }^{c}$ Yasuhiko Baba, ${ }^{d}$ \\ Toshihiro Tanioka, ${ }^{c}$ Toru Watanabe, ${ }^{a, b}$ and Tadanori Sasaki ${ }^{a}$ \\ ${ }^{a}$ Departmant of Hospital Pharmaceutics, School of Pharmacy, Showa University; 1-5-8 Hatanodai, Shinagawa-ku, Tokyo \\ 142-8555, Japan: ${ }^{b}$ Department of Pharmacy, Showa University Fujigaoka Hospital; 1-30 Fujigaoka, Aoba-ku, Yokohama \\ 227-8501, Japan: 'Department of Pharmacology, Toxicology and Therapeutics, Division of Physiology and Pathology, School \\ of Pharmacy, Showa University; 1-5-8 Hatanodai, Shinagawa-ku, Tokyo 142-8555, Japan: and 'Department of Neurology, \\ Showa University Fujigaoka Hospital; 1-30 Fujigaoka, Aoba-ku, Yokohama 227-8501, Japan.
}

(Received April 6, 2020; Accepted August 4, 2020)

\begin{abstract}
The treatment of acute ischemic stroke usually involves argatroban administration by continuous infusion for $2 \mathrm{~d}$ and by intravenous infusion twice a day for $5 \mathrm{~d}$ after that. However, the appropriate dose of argatroban to be administered is not clear. Therefore, no studies have been reported a comparison of intravenous and continuous argatroban infusion after day 3 for acute ischemic stroke patients. We aimed to identify the connection between differences in argatroban administration and worsening of symptoms after day 3 in ischemic stroke patients. We retrospectively evaluated the data of 107 ischemic stroke patients who received treatment with argatroban. The study endpoint was defined as the worsening of symptoms from days 3 to 7 . Logistic regression analysis was used to determine the risk factors that were significantly associated with worsening of symptoms. Patients were administered argatroban, with rates of $72.0 \%$, and $28.0 \%$ for continuous, and intravenous infusion, respectively. A total of $10(9.3 \%)$ patients experienced worsening of symptoms. In the single logistic regression analysis, carotid stenosis [non-adjusted odds ratio (OR) 5.775, $95 \%$ confidence interval (CI) $1.486-22.442, p=0.011]$ was only significantly associated with worsening of symptoms. Worsening of symptoms was not related to either intravenous or continuous infusion group $(16.7 \% v s .6 .5 \%, p=$ $0.104)$. Bleeding was also not associated with either group $(6.7 \% v s .3 .9 \%, p=0.618)$. We suggest that the differences in the mode of argatroban administration were not related to the worsening of symptoms in ischemic stroke patients. We also found that safety was equivalent regardless of the administration route.
\end{abstract}

Key words_ argatroban; ischemic stroke; continuous infusion; worsening of symptom; bleeding; risk factor

緒 $\quad \overline{\overline{\bar{~}}}$

脳血管疾患の 1 年間の死亡数は 10 万 8165 人で, 悪性新生物，心疾患（高血圧を除く）につぐ国内全 死因の第 3 位を占めており，その約 $55 \%$ が脳梗塞/ transient ischemic attack（TIA）で占めている. ${ }^{1)}$ 特に, 日本脳卒中データバンク報告書 2019 年によ ると脳梗塞/TAI の増加が顕著となつている. ${ }^{2) ま}$ た，「国民生活基礎調査」の介護が必要となつた主

$a$ 昭和大学薬学部病院薬剤学講座, $b$ 昭和大学藤が丘病 院薬剂部, $c$ 昭和大学薬学部基礎医療薬学講座生理 - 病 態学部門, $d$ 昭和大学藤が丘病院脳神経内科

*e-mail: tomiko-s@ @med.showa-u.ac.jp
な原因は，男性においては脳血管疾患が $25.7 \%$ と 最も多く，社会的，経済的に国民全体に大きな影響 を及ぼす疾患である. ${ }^{3)}$ 現在, 日本脳卒中学会と日 本循環器学会の連携の下, 健康長寿を達成するため に「脳卒中と循環器病克服 5 か年計画」が 2016 年 に公開され，国として取り組んでいる問題である.

急性期脳梗塞における薬物療法はその脸梗塞病態 や発症時間によって, 脳保護薬，抗血小板薬，抗凝 固薬，抗脳浮腫薬等が使い分けられる。抗血栓療法 としては, 抗血小板薬のオザグレルナトリウム, ア スピリン，抗凝固薬のアルガトロバン，ヘパリンが 一般的に使用される。脳卒中ガイドライン 2015 に よるとアテローム性脳梗塞では，急性期抗凝固療法 
として 48 時間以内であれば，アルガトロバンを使 用することが推奨されている. ${ }^{4)}$ アルガトロバンは 国内で開発されたアンチトロンビン III 非依存的に抗 凝固作用を有する選択的な合成抗トロンビン阻害薬 である. ${ }^{5)}$ 本剤は発症 48 時間以内の脳血栓症（特に 皮質梗塞）に有用であり，出血性合併症が少ないと 報告されている. 6,7) 特に，プラセボを対照とした多 施設二重盲検群間比較試験では，発症 48 時間以内 の急性期脳血栓症（ラクナ梗塞を除く）において神 経症状の改善（アルガトロバン群で $54.2 \%$ ，プラ セボ群で $23.7 \%)$, 出血合併症が少ないことが報告 されている. ${ }^{6}$

急性期脳梗塞治療におけるアルガトロバンは通常 添付文書に基づいた使用法であれば，使用開始 2 日 間は $60 \mathrm{mg}$ を 24 時間かけて持続点滴静注し，3 日 目以降は 1 日 2 回 1 回 $10 \mathrm{mg}$ を点滴静注されるも のである。しかし，実臨床におけるアルガトロバン の用法用量は様々であり，5 日目に持続点滴から切 り替えた後に神経症状が悪化するという報告8)があ る一方で，7 日間持続点滴静注にて症状が著明に改 善した報告もされている. ${ }^{9)}$ また，持続点滴につい てはアテローム性血栓性脳梗塞の発症後のトロンビ ン産生が有意に抑制されたという見解もある. ${ }^{10)} こ$ のように，アルガトロバンにおける用法用量につい ては様々な報告がされている。しかしながら，これ まで従来通り 3 日目以降点滴静注をした場合と持続 点滴を継続した場合を比較検討した報告はない.

そこで，本研究では，急性期脳梗塞で入院し，ア ルガトロバンを投与した患者を対象に，添付文書に 従って 3 日目以降点滴静注した場合と持続点滴を継 続した場合のその後の症状悪化の有無や出血事象を 調査し，アルガトロバンの投与方法と症状悪化の関 連性について検討することを目的とした。

\section{方法}

1. 対象患者 2015 年 1 月から 2018 年 12 月 に昭和大学藤が丘病院に入院し，アルガトロバンを 投与したアテローム性脳梗塞患者 107 名を対象とし た．除外基準は，該当検查值の不実施でデータが不 十分であった患者とした。

2. 治療アルガトロバンによる治療は，以下 のように定義した．添付文書に沿つた投与群（normal group）は，はじめの 2 日間は 1 日 $60 \mathrm{mg}$ を 24
時間かけて持続点滴静注し，その後 5 日間は 1 回 $10 \mathrm{mg}$ を 1 日朝夕 2 回, 1 回 3 時間かけて点滴静注 した。持続点滴静注投与群 (continuous infusion group）は，はじめの 2 日間は 1 日 $60 \mathrm{mg}$ を 24 時 間かけて持続点滴静注し，その後も 1 日 $60 \mathrm{mg}$ 以 内の用量を 24 時間かけて持続点滴を継続して投与 した.

3. 調査項目 調査項目は，アルガトロバン投 与方法，年齢，性別，body mass index (BMI), 収 縮期血圧，拡張期血圧，既往歴の有無（糖尿病，高 血圧，脂質異常症，心房細動，脳梗塞，腎機能低 下，頸動脈狭窄）， branch atheromatous disease （BAD）疑い，投与 7 日目までの症状悪化の有無， 薬歴 [抗凝固薬，利尿薬， Ca 拮抗薬， angiotensinconverting enzyme (ACE) 阻害薬/angiotensin II receptor blocker(ARB), スタチン, 抗血小板薬], 入院時の臨床検查值 [white blood cell (WBC), hemoglobin $(\mathrm{Hb})$, platelet (PLT), aspartate aminotransferase (AST), alanine aminotransferase (ALT), creatinine (Cre), estimated glomerular filtration rate (eGFR)], 入院時の Glasgow Coma Scale（GCS）とした。また, tissue plasminogen activator（t-PA）の投与の有無，血栓回収療法の有 無，入院中に使用した薬剤（エダラボン，グリセ オール，低分子デキストラン)，入院開始 3 日目ま での抗血小板薬の使用方法（アスピリン単独，クロ ピドグレル単独, シロスタゾール単独，アスピリン +クロピドグレル，アスピリン＋シロスタゾー ル，クロピドグレル＋シロスタゾール）を調査し た.

4. エンドポイント アルガトロバン投与 3 日 目から投与 7 日目における症状悪化の有無とした. 本研究においてアルガトロバンの投与方法は初日, 2 日目は全例同じである。 また，添付文書通りに投 与した場合，最終投与日は 7 日目に該当する. アル ガトロバンの半期は約 40 分と短いため, 最終投与 日までにおける症状の悪化の有無を調査した.

症状悪化の判定は，医師が画像診断を行い診療録 に症状悪化を記載した “梗塞栄の拡大” や“患者の 麻痺症状又は脳卒中重症度評価スケールである $\mathrm{Na}$ tional Institute of Health Stroke Scale (NIHSS) の 悪化”の有無とし, 調査を行った。 また, 出血の判 定は，医師が診療録に出血発現を記載した内容の有 
Table 1. Patient Characteristics $(n=107)$

\begin{tabular}{|c|c|c|c|c|}
\hline Variables & $\begin{array}{c}\text { total } \\
(n=107) \\
\text { mean } \pm \text { S.D. }\end{array}$ & $\begin{array}{c}\text { normal group } \\
\quad(n=30) \\
\text { median (interquartile } \\
\text { range) or mean } \pm \text { S.D. }\end{array}$ & $\begin{array}{c}\text { ci group } \\
(n=77) \\
\text { median (interquartile } \\
\text { range) or mean } \pm \text { S.D. }\end{array}$ & $p$-value \\
\hline Age, years & $73.5 \pm 12.0$ & $74.5(68.0-81.0)$ & $75.0(68.0-82.0)$ & 0.781 \\
\hline Sex, $n(\%)$ & & & & 0.559 \\
\hline Male & $74(69.2)$ & $22(73.3)$ & $52(67.5)$ & \\
\hline Female & $33(30.8)$ & $8(26.7)$ & $25(32.5)$ & \\
\hline BMI $\left(\mathrm{kg} / \mathrm{m}^{2}\right)$ & $22.7 \pm 3.2$ & $22.9(20.3-24.5)$ & $22.2(20.7-23.9)$ & 0.670 \\
\hline $\mathrm{SBP}(\mathrm{mmHg})$ at admission & $163.1 \pm 27.6$ & $156.0 \pm 25.6$ & $165.8 \pm 28.0$ & 0.099 \\
\hline DBP $(\mathrm{mmHg})$ at admission & $85.6 \pm 15.6$ & $80.0(74.0-97.0)$ & $84.0(75.0-99.0)$ & 0.328 \\
\hline $\mathrm{WBC}\left(\times 10^{3} / \mu \mathrm{L}\right)$ & $6.9 \pm 2.3$ & $6.9(5.8-8.5)$ & $6.2(5.1-7.7)$ & 0.091 \\
\hline $\mathrm{Hb}(\mathrm{g} / \mathrm{dL})$ & $13.6 \pm 2.1$ & $13.6(11.9-14.9)$ & $13.9(13.0-14.8)$ & 0.517 \\
\hline $\operatorname{PLT}\left(\times 10^{4} / \mu \mathrm{L}\right)$ & $21.1 \pm 5.6$ & $22.3(19.0-24.9)$ & $20.1(16.8-23.7)$ & 0.204 \\
\hline Cre $(\mathrm{mg} / \mathrm{mL})$ & $1.0 \pm 0.8$ & $0.90(0.68-1.11)$ & $0.78(0.63-0.95)$ & 0.063 \\
\hline eGFR $\left(\mathrm{mL} / \mathrm{min} / 1.73 \mathrm{~m}^{2}\right)$ & $67.8 \pm 25.4$ & $62.4 \pm 21.6$ & $69.8 \pm 26.5$ & 0.179 \\
\hline AST (IU/L) & $25.3 \pm 15.9$ & $22.0(16.0-28.0)$ & $23.0(17.0-28.0)$ & 0.537 \\
\hline $\mathrm{ALT}(\mathrm{IU} / \mathrm{L})$ & $20.1 \pm 14.1$ & $18.0(11.0-22.0)$ & $17.0(13.0-22.0)$ & 0.546 \\
\hline GCS at admission & & & & 0.266 \\
\hline 15 points & $92(86.0)$ & $24(80.0)$ & $68(88.3)$ & \\
\hline$<15$ points & $15(14.0)$ & $6(20.0)$ & $9(11.7)$ & \\
\hline \multicolumn{5}{|l|}{ Medical history, $n(\%)$} \\
\hline Diabetes mellitus & $42(39.3)$ & $9(30.0)$ & $33(42.9)$ & 0.221 \\
\hline Hypertenstion & $77(72.0)$ & $20(66.7)$ & $57(74.0)$ & 0.447 \\
\hline Hyperlipidemia & $45(42.1)$ & $12(40.0)$ & $33(42.9)$ & 0.489 \\
\hline Atrial fibrillation & $12(11.2)$ & $5(16.7)$ & $7(9.1)$ & 0.265 \\
\hline Stroke & $27(25.2)$ & $9(30.0)$ & $18(23.4)$ & 0.479 \\
\hline Poor renal function & $17(15.9)$ & $8(26.7)$ & $16(20.8)$ & 0.057 \\
\hline Carotid stenosis & $26(24.3)$ & $10(33.3)$ & $16(20.8)$ & 0.174 \\
\hline Branch atheromatous disease suspect & $34(31.8)$ & $8(26.7)$ & $26(33.8)$ & 0.479 \\
\hline \multicolumn{5}{|l|}{ Drugs hisotry, $n(\%)$} \\
\hline Anticoagulant & $6(5.6)$ & $3(10.0)$ & $3(3.9)$ & 0.348 \\
\hline Diuretic & $14(13.1)$ & $4(13.3)$ & $10(13.0)$ & $<1.000$ \\
\hline Calcium antagonist & $45(42.1)$ & $15(50.0)$ & $30(39.0)$ & 0.236 \\
\hline $\mathrm{ACE}$ inhibitor/ARB & $43(40.2)$ & $13(43.3)$ & $30(39.0)$ & 0.583 \\
\hline Statin & $29(27.1)$ & $8(26.7)$ & $21(27.3)$ & 0.949 \\
\hline Antiplatelet drug & $36(33.6)$ & $11(36.7)$ & $25(32.5)$ & 0.608 \\
\hline
\end{tabular}

ci: continuous infusion, BMI: body mass index, SBP: systolic blood pressure, DBP: diastolic blood pressure, WBC: white blood cell, Hb: hemoglobin, PLT: platelet, Cre: creatinine, eGFR: estimated glomerular filtration rate, AST: aspartate aminotransferase, ALT: alanine aminotransferase, GCS: Glasgow Coma Scale, ACE: angiotensin-converting enzyme, ARB: angiotensin II receptor blocker.

無とし，同様に調査を行った．

本症例の多くは Stroke Care Unit で管理されて いるため, 症状悪化や出血においての画像評価, 観 察項目や観察タイミングのばらつきは少ないという 前提で調査している.

\section{5. 統計解析アルガトロバンを投与した急性} 期脳梗塞患者において，投与 3 日目から投与 7 日目 までの症状悪化の有無を調査し， 2 群（normal group vs. continuous infusion group) に層別化し,
比較検討した． 2 群間の比較は $\chi^{2}$ 検定又は $t$ 検定を 用いた。期待度数が $5 \%$ 未満の場合は，Fisher の直 接確立検定を行った。また，正規性は Shapiro-wilk 検定で確認し，非正規分布を示したデー夕に関して は Mann-Whiteny $U$ 検定を用いた。また，単ロジ スティック回帰分析（強制投入法）にて症状悪化に 対する寄与度（非調整 odds ratio；非調整 OR）及 びその $95 \%$ 信頼区間（confidence interval; CI）を 算出した。本研究は，両側検定 $<0.05$ を統計学的 
有意とみなした。解析ソフトは IBM SPSS Statistics 23.0 （IBM）を使用した.

6. 倫理的事項 本研究は, 昭和大学藤が丘病 院臨床試験審査委員会の承認を得ている（承認番 号：F2017C46).

\section{結果}

1. 患者背景 対象となつた 107 人の患者背景 を Table 1 に示す。107 例のうち, normal group が 30 例, continuous infusion group が 77 例であっ た。 入院時 GCS が最軽症 15 点の患者は 92 例 (86.0\%) であった。平均年齢は $73.5 \pm 12.0$ 歳，男 女比は男性 74 例 $(69.2 \%)$ ，女性 33 例（30.8\%） と男性の割合が多かった。 Normal group と continuous infusion group を比較した結果，患者背景 の入院時情報，既往歴，薬歴，臨床検査值におい て，いずれの項目においても両群間で有意差は認め られなかった。

症状の悪化がなかった患者において normal group と continuous infusion group を比較した結 果，唯一，CKD ありの患者は添付文書通りに使用 している割合が高かった（28\% vs. $11.1 \% ; p=$ 0.044)。一方，症状の悪化が認められ患者において は, normal group と continuous infusion group $の$ 間に明らかな違いは認められなかった。

2. 入院後の使用薬剂状況 入院後の使用薬剤 状況を Table 2 に示す。入院後使用した薬剤におい ては，t-PA $2.8 \% ，$ エダラボン $70.1 \%$ ，低分子デキ ストラン $34.6 \%$ でった。 また，抗血小板薬の使 用はアスピリン +クロピドグレルの抗血小板薬 2 剂併用療法（dual antiplatelet therapy; DAPT）が $52.3 \%$ と最も多かった．抗血小板薬の単剂使用患者 は，心房細動の既往があり抗凝固薬を内服している 患者がほとんどであった。

3. 症状悪化に対する単変量解析と非調整 OR 症状悪化については, ありの患者が 10 例，なし の患者が 97 例であった。アテローム性脳梗塞患者 の入院後症状悪化に関連する因子を Table 3 に示 す．頸動脈狭窄の既往がある患者において，症状悪 化の割合が有意に高率であった（60.0\% vs. 20.6\%， $p=0.013)$ 。また，入院前に ACE 阻害薬又は ARB を使用していた患者は，症状悪化の割合が有意に高 率であった (70.0\% vs. 37.1\%, $p=0.046)$ 。一方で,
Table 2. Medication after Admission $(n=107)$

\begin{tabular}{|c|c|c|c|}
\hline & $\begin{array}{c}\text { total } \\
n=107\end{array}$ & $\begin{array}{c}\text { normal } \\
\text { group } \\
n=30\end{array}$ & $\begin{array}{c}\text { ci group } \\
n=77\end{array}$ \\
\hline $\begin{array}{l}\text { Thromus collection therapy, } \\
\qquad(\%)\end{array}$ & 0 & 0 & 0 \\
\hline $\begin{array}{l}\text { Tissue plasminogen activator, } \\
\qquad n(\%)\end{array}$ & $3(2.8)$ & 0 & $3(3.9)$ \\
\hline \multicolumn{4}{|l|}{ Drugs at admission, $n(\%)$} \\
\hline Edaravone & $75(70.1)$ & $21(70.0)$ & $54(70.1)$ \\
\hline Glyceol & $5(4.7)$ & 0 & $5(6.5)$ \\
\hline Low molecular dextran & $37(34.6)$ & $12(40.0)$ & $25(32.5)$ \\
\hline \multicolumn{4}{|c|}{ Antiplatelet drugs from admission to day $3, n(\%)$} \\
\hline Aspirin & $18(16.8)$ & $5(16.7)$ & $13(16.9)$ \\
\hline Clopidogrel & $2(1.9)$ & 0 & $2(2.6)$ \\
\hline Cilostazol & $4(3.7)$ & $1(3.3)$ & $3(3.9)$ \\
\hline Aspirin + Clopidogrel & $56(52.3)$ & $15(50.0)$ & $41(53.2)$ \\
\hline Aspirin + Cilostazol & $12(11.2)$ & $3(10.0)$ & $9(11.7)$ \\
\hline Clopidogrel + Cilostazol & $10(9.3)$ & $5(16.7)$ & $5(6.5)$ \\
\hline
\end{tabular}

ci: continuous infusion.

年齢や性別，既往歴，臨床検査值において有意差は 認められなかった。

単ロジスティック回帰分析の結果，症状悪化に寄 与する有意な因子として, 唯一, 頸動脈狭窄が抽出 された（非調整 OR 5.775：95\%CI 1.486-22.442, $p=0.011$, Table 4).

4. アルガトロバン投与方法の違いによる有効性 と安全性 アルガトロバン投与方法において, normal group $と$ continuous infusion group におい て両群間で症状悪化の有意差は認められなかった (16.7\% vs. 6.5\%; $p=0.104$, Table 5). また, 出血 事象においても， normal group は 2 例 $(6.7 \%)$, continuous infusion group は 3 例 $(3.9 \%)$ で，い ずれも有意差は認められなかった $(p=0.618)$.

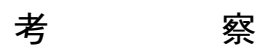

本研究において, 急性期脳梗塞患者に対するアル ガトロバンの使用方法は, normal group と continuous infusion group を比較した結果，患者背 景・薬歴の各項目に関連性は認められなかつた。ま た, 脳梗塞の症状悪化や出血の有害事象においても アルガトロバンの投与方法との関連性は認められな かった．そのため，いずれの投与方法で治療を行っ た場合も安全性は担保されていることが示唆された.

本研究においては，どちらの投与方法が有益であ るかについては結果を示すことはできなかったが, 
Table 3. Univariate Analysis of the Risk Factors for Worsening of Symptoms

\begin{tabular}{|c|c|c|c|}
\hline Variables & $\begin{array}{l}\text { worse group } \\
\quad(n=10) \\
\text { median (interquartile } \\
\text { range) or mean } \pm \text { S.D. }\end{array}$ & $\begin{array}{l}\text { no change group } \\
\quad(n=97) \\
\text { median (interquartile } \\
\text { range) or mean } \pm \text { S.D. }\end{array}$ & $p$-value \\
\hline Age, years & $73.0(65.0-78.0)$ & $75.0(69.0-81.0)$ & 0.720 \\
\hline Sex, $n(\%)$ & & & 0.710 \\
\hline Male & $8(80.0)$ & $66(68.0)$ & \\
\hline Female & $2(20.0)$ & $31(32.0)$ & \\
\hline BMI $\left(\mathrm{kg} / \mathrm{m}^{2}\right)$ & $21.5(20.3-28.2)$ & $23.2(20.3-24.1)$ & 0.528 \\
\hline $\mathrm{SBP}(\mathrm{mmHg})$ at admission & $156.9 \pm 30.2$ & $163.7 \pm 27.4$ & 0.461 \\
\hline $\mathrm{DBP}(\mathrm{mmHg})$ at admission & $70.0(68.0-84.0)$ & $80.0(77.0-97.0)$ & 0.301 \\
\hline $\mathrm{WBC}(/ \mu \mathrm{L})$ & $6.3(5.4-7.4)$ & $7.0(5.9-8.5)$ & 0.435 \\
\hline $\mathrm{Hb}(\mathrm{g} / \mathrm{dL})$ & $14.0(13.4-14.7)$ & $13.4(11.9-14.9)$ & 0.902 \\
\hline $\operatorname{PLT}\left(\times 10^{4} / \mu \mathrm{L}\right)$ & $21.7(17.2-26.4)$ & $22.3(19.2-24.7)$ & 0.634 \\
\hline Cre $(\mathrm{mg} / \mathrm{mL})$ & $0.91(0.85-1.02)$ & $0.88(0.68-1.11)$ & 0.096 \\
\hline eGFR $\left(\mathrm{mL} / \mathrm{min} / 1.73 \mathrm{~m}^{2}\right)$ & $56.3 \pm 19.3$ & $69.0 \pm 25.7$ & 0.134 \\
\hline $\operatorname{AST}(\mathrm{IU} / \mathrm{L})$ & $26.0(26.0-30.0)$ & $21.0(16.0-26.0)$ & 0.164 \\
\hline $\operatorname{ALT}(\mathrm{IU} / \mathrm{L})$ & $22.0(12.0-26.0)$ & $18.0(11.0-21.0)$ & 0.940 \\
\hline Route, $n(\%)$ & & & 0.104 \\
\hline Normal & $5(50.0)$ & $25(25.8)$ & \\
\hline Continuous infusion & $5(50.0)$ & $72(74.2)$ & \\
\hline GCS at admission, $n(\%)$ & & & $<1.000$ \\
\hline 15 points & $9(90.0)$ & $83(85.6)$ & \\
\hline$<15$ points & $1(10.0)$ & $14(14.4)$ & \\
\hline \multicolumn{4}{|l|}{ Medical history, $n(\%)$} \\
\hline Diabetes mellitus & $4(40.0)$ & $38(39.2)$ & $<1.000$ \\
\hline Hypertenstion & $7(70.0)$ & $70(72.2)$ & $<1.000$ \\
\hline Hyperlipidemia & $4(40.0)$ & $41(42.3)$ & $<1.000$ \\
\hline Atrial fibrillation & $2(20.0)$ & $10(10.3)$ & 0.310 \\
\hline Stroke & $0(0.0)$ & $27(27.8)$ & 0.620 \\
\hline Poor renal function & $2(20.0)$ & $15(15.5)$ & 0.568 \\
\hline Carotid stenosis & $6(60.0)$ & $20(20.6)$ & 0.013 \\
\hline Branch atheromatous disease suspect & $4(40.0)$ & $30(30.9)$ & 0.723 \\
\hline \multicolumn{4}{|l|}{ Drugs hisotry, $n(\%)$} \\
\hline Anticoagulant & $1(10.0)$ & $5(5.2)$ & 0.457 \\
\hline Diuretic & $3(30.0)$ & $11(11.3)$ & 0.126 \\
\hline Calcium antagonist & $7(70.0)$ & $38(39.2)$ & 0.064 \\
\hline $\mathrm{ACE}$ inhibitor/ARB & $7(70.0)$ & $36(37.1)$ & 0.046 \\
\hline Statin & $4(40.0)$ & $25(25.8)$ & 0.335 \\
\hline Antiplatelet drug & $3(30.0)$ & $33(34.0)$ & $<1.000$ \\
\hline
\end{tabular}

ci: continuous infusion, BMI: body mass index, SBP: systolic blood pressure, DBP: diastolic blood pressure, WBC: white blood cell, Hb: hemoglobin, PLT: platelet, Cre: creatinine, eGFR: estimated glomerular filtration rate, AST: aspartate aminotransferase, ALT: alanine aminotransferase, GCS: Glasgow Coma Scale, ACE: angiotensin-converting enzyme, ARB: angiotensin II receptor blocker.

従来，持続点滴継続投与は添付文書とは異なる投与 方法であり明確なエビデンスは存在しない。そのた め，医師の裁量で選択されてきたことを踏まえる と, 本研究により持続点滴継続投与の安全性が示唆 されたと考えられる。一方で，本研究中において， 頸動脈狭窄の既往が急性期脳梗塞治療中の患者の症 状悪化に関連していることが示唆され，頸動脈狭窄
ありの患者はない患者と比較して症状悪化のリスク が 5.8 倍高いことが示された。頸動脈狭窄の病態生 理として，血行力学性に血流不全を生じるような狭 窄病変はプラーク破綻や血栓形成を生じ易いため, 塞栓源ともなり易いと言われている. ${ }^{10)}$ 本研究にお いても，頸動脈狭窄のある患者は症状悪化と関連性 が認められたため, 脳梗塞治療中に頸動脈狭窄部の 
Table 4. Single Logistic Regression Analysis of the Risk Factors for Worsening of Symptoms

\begin{tabular}{|c|c|c|c|c|}
\hline Variables & $\beta$ & non-adjusted odds ratio & $95 \% \mathrm{CI}$ & $p$-value \\
\hline Age, years & 0.020 & 1.020 & $0.962-1.082$ & 0.511 \\
\hline Sex (male $v s$. female), $n(\%)$ & -0.631 & 0.532 & $0.107-2.655$ & 0.442 \\
\hline BMI $\left(\mathrm{kg} / \mathrm{m}^{2}\right)$ & 0.076 & 1.079 & $0.890-1.308$ & 0.440 \\
\hline SBP $(\mathrm{mmHg})$ at admission & -0.009 & 0.991 & $0.967-1.015$ & 0.458 \\
\hline DBP $(\mathrm{mmHg})$ at admission & -0.027 & 0.973 & $0.929-1.020$ & 0.257 \\
\hline $\mathrm{WBC}(/ \mu \mathrm{L})$ & 0.063 & 1.065 & $0.813-1.396$ & 0.646 \\
\hline $\mathrm{Hb}(\mathrm{g} / \mathrm{dL})$ & 0.005 & 1.005 & $0.733-1.378$ & 0.976 \\
\hline $\operatorname{PLT}\left(\times 10^{4} / \mu \mathrm{L}\right)$ & -0.020 & 0.980 & $0.870-1.104$ & 0.741 \\
\hline Cre $(\mathrm{mg} / \mathrm{mL})$ & 0.105 & 1.111 & $0.560-2.203$ & 0.763 \\
\hline eGFR $\left(\mathrm{mL} / \mathrm{min} / 1.73 \mathrm{~m}^{2}\right)$ & -0.020 & 0.980 & $0.954-1.006$ & 0.980 \\
\hline $\operatorname{AST}(\mathrm{IU} / \mathrm{L})$ & 0.000 & 1.000 & $0.960-1.042$ & 0.995 \\
\hline $\operatorname{ALT}(\mathrm{IU} / \mathrm{L})$ & 0.000 & 1.000 & $0.955-1.048$ & 0.999 \\
\hline Route (nomal vs. ci), $n(\%)$ & -1.058 & 0.347 & $0.093-1.300$ & 0.116 \\
\hline GCS at admission ( 15 point $v s .<15$ points), $n(\%)$ & -0.417 & 0.659 & $0.077-5.611$ & 0.703 \\
\hline \multicolumn{5}{|l|}{ Medical history, $n$ (\%) } \\
\hline Diabetes mellitus & 0.034 & 1.035 & $0.274-3.911$ & 0.959 \\
\hline Hypertenstion & -0.105 & 0.911 & $0.217-3.737$ & 0.885 \\
\hline Hyperlipidemia & -0.094 & 0.911 & $0.241-3.435$ & 0.890 \\
\hline Atrial fibrillation & 0.777 & 2.175 & $0.405-11.694$ & 0.365 \\
\hline Stroke & - & - & - & - \\
\hline Poor renal function & 0.312 & 1.357 & $0.264-7.076$ & 0.710 \\
\hline Carotid stenosis & 1.754 & 5.775 & $1.486-22.442$ & 0.011 \\
\hline Branch atheromatous disease suspect & 0.398 & 1.489 & $0.391-5.666$ & 0.559 \\
\hline \multicolumn{5}{|l|}{ Drugs hisotry, $n(\%)$} \\
\hline Anticoagulant & 0.704 & 2.022 & $0.212-19.256$ & 0.540 \\
\hline Diuretic & 1.197 & 3.312 & $0.745-14.712$ & 0.116 \\
\hline Calcium antagonist & 1.270 & 3.561 & $0.867-14.631$ & 0.078 \\
\hline ACE inhibitor/ARB & 1.331 & 3.784 & $0.921-15.548$ & 0.065 \\
\hline Statin & 0.652 & 1.920 & $0.500-7.365$ & 0.342 \\
\hline Antiplatelet drug & -0.185 & 0.831 & $0.202-3.426$ & 0.798 \\
\hline
\end{tabular}

Odds ratio $=\exp (\beta)$, CI: confidence interval, ci: continuous infusion, BMI: body mass index, SBP: systolic blood pressure, DBP: diastolic blood pressure, WBC: white blood cell, Hb: hemoglobin, PLT: platelet, Cre: creatinine, eGFR: estimated glomerular filtration rate, AST: aspartate aminotransferase, ALT: alanine aminotransferase, GCS: Glasgow Coma Scale, ACE: angiotensin-converting enzyme, ARB: angiotensin II receptor blocker.

Table 5. Univariate Analysis of the Outcome for Effectiveness and Safety

\begin{tabular}{lrccc}
\hline \hline & total & normal group & ci group & \\
& $n=107$ & $n=30$ & $n=77$ & $p$-value \\
\hline worse, $n(\%)$ & $10(9.3)$ & $5(16.7)$ & $5(6.5)$ & 0.104 \\
bleeding, $n(\%)$ & $5(4.7)$ & $2(6.7)$ & $3(3.9)$ & 0.618 \\
\hline
\end{tabular}

ci: continuous infusion.

プラーク破綻，又は新規血栓形成が起こつた可能性 も考えられる，そのため，頸動脈狭窄がある患者に おいては, 脳梗塞治療のためのアルガトロバン投与 中の脳梗塞の症状悪化を注意深く観察していく必要 があると考えられる。

急性期脳梗塞患者の早期神経学的悪化又は再発を
防ぐために抗凝固療法や抗血小板療法が行われる. 近年，穿通枝梗塞に症状が進行し易い BAD が多い と示唆されており, ${ }^{11)}$ 領域によって異なるものの BAD 患者の $23.0-43.6 \%$ は，入院後神経症状の増悪 を呈していることが報告されている. ${ }^{12-15)}$ 本研究で は，症状悪化ありの患者で BAD（疑いを含む）は 4 例 (40.0\%) であり同様の傾向が認められた。し かしながら, 症状悪化症例が少なかつたため, BAD と症状悪化の関連は認められなかった。

本研究では, 症状悪化が認められた患者及び症状 悪化が認められなかった患者においても，それぞれ 点滴静注群と持続点滴群の比較検討を行つたが，ほ とんど明らかな違いは認められなかった，唯一，症 状の悪化が認められなかった CKD ありの患者は添 
付文書通りに使用している割合が高いことを示した が，eGFRにおいては両群間で明らかな違いは認め られなかった，そのため，患者の投与方法における 個別化を推測するのは今後の課題と考えられる.

脳卒中治療ガイドライン 2015 によると，急性期 抗血小板療法のアスピリンとクロピトグレル 3 週間 の DAPT 療法はアスピリン単剤に比べて，3 カ月 後の脳卒中再発を有意に抑制し, 中等症若しくは重 篤な出血事故を増加させないとされている. ${ }^{16)} ま$ た，脳梗塞慢性期の DAPT 療法の有用性と安全性 は，シロスタゾールにおいてもアスピリン又はクロ ピトグレル単剤治療と比較して脳梗塞予防効果が向 上し，かつ安全性についても同等であることが示さ れている. ${ }^{17)}$ 脳梗塞患者の入院 3 日目までの抗血小 板薬の使用方法は, DAPT 療法が 78 例 $(72.9 \%)$ と最も多く，脳卒中ガイドライン 20154)に準じた 治療が行われていることが示された。 また，抗血小 板薬単剂であった患者の多くは，心房細動の既往の ため抗凝固薬を内服しており, 出血リスクを考慮し た結果と考えられた，今回，本研究において，出血 が認められた患者 5 例は, 全例 7 日目以降かつ 3 週 間以内に出血が認められたため, 出血例はいずれも アルガトロバンの影響ではなく, DAPT 療法によ る出血の可能性が高いと考えられた。 また, 脳梗塞 患者における降圧療法も重要である。降圧薬の選択 としては, Ca 拮抗薬, 利尿薬, ACE 阻害薬,

$\mathrm{ARB}$ などが強く推奨されている. ${ }^{4}$ 本研究におい て，いずれの降圧薬においても入院前に使用してい た患者は, 症状悪化の割合が高い傾向が認められ た.このことから，脳梗塞発症前に多剂併用による 降圧コントロールが必要であった患者は, 脳梗塞治 療中, 症状悪化に進展する可能性があるかもしれな い.

本研究の限界としては, 第一に, 後ろ向きコホー 卜研究であるため診療録から得られる情報が不十分 であったと考えられる，特に，脳卒中重症度評価ス ケールであるNIHSS を用いた症状悪化の評価が困 難であったため, GCS で評価を行った。第二に, 持続点滴のアルガトロバンの用量において 3 日目以 降，異なつた症例が含まれているため，正確な臨床 効果と有害事象を行うためには不十分であったと考 えられる. しかしながら, 本研究は点滴静注と持続 点滴との比較検討であり投与方法における比較は可
能であったと考えられる，第三に，症状悪化ありは 10 例と少なく単ロジスティック回帰分析での検討 になった点である．第四に，単施設でサンプルサイ ズが少なく，長期的な予後に関しては検討していな い.しかしながら, 本研究は, 急性期脳梗塞のアル ガトロバンについて検討しており，短期評価につい ては十分な調査期間であったと考えられる。 また, 点滴静注群と持続点滴群の患者背景に大きな違いが 認められなかったため, 投与方法による患者の選択 バイアスは少ないと考えられる.

今回, 本研究によって, アルガトロバンの使用方 法の違いは, 出血事象及び 3 日目以降の症状悪化に 影響していない可能性が示唆された。 また, 唯一, アテローム性脳梗塞患者におけるアルガトロバン使 用 3 日目以降の症状悪化に, 頸動脈狭窄の既往の関 連が示唆された. 今後, サンプルサイズを増やし, 多施設を含めた検討をしていく必要があると考えら れる。

利益相反＼cjkstart開示すべき利益相反はない.

\section{REFERENCES}

1) Ministry of Health, Labour and Welfare. “Vital Statistics 2018.": 〈https://www.mhlw. go.jp / toukei / saikin / hw / jinkou / geppo / nengai18/index.html $\rangle$, cited 3 March, 2020.

2) Japan Stroke Data Bank. "Grasping the actual situation of stroke medical care in Japan stroke registry 2019."’: 〈http://strokedata bank.ncvc.go.jp/2019/12/02/post-589-2-2/>, cited 3 March, 2020.

3) Ministry of Health, Labour and Welfare. "Graphical Review of Japanese Household. from Comprehensive Survey of Living Conditions, 2016."’:〈https://www.mhlw.go.jp/tou kei/list/20-21.html $\rangle$, cited 3 March, 2020.

4) The Japan Stroke Society, "Japanese Guidelines for the Management of Stroke 2015," KYOWA KIKAKU Ltd., Tokyo, 2017.

5) Kataoka H., Jpn. J. Neurosurg. (Tokyo), 25, 804-812 (2016).

6) Tazaki Y., Kobayashi S., Togi H., Ohtomo E., Goto F., Araki G., Kodama R., Kanda T., Ito E., Sawada T., Fujishima M., Sakuma A., Tsutani K., Kan S., J. Clin. Exp. Med., 161, 
887-907 (1992).

7) Kobayashi S., Tazaki Y., Semin. Thromb. Hemost., 23, 531-534 (1997).

8) Higuchi E., Uchiyama Y., Iizima M., Kitagawa K., Jpn. J. Stroke, 37, 446-451 (2015) .

9) Kikui S., Sawa N., Nishiwaki T., Jpn. J. Stroke, 32, 482-485 (2010).

10) Yamazaki M., Uchiyama S., Brain Nerve, 62, 1269-1275 (2010).

11) Steinke W., Ley S. C., Stroke, 33, 1510-1516 (2002).

12) Nagakane Y., Naritomi H., Oe H., Nagatsuka K., Yamawaki T., Eur. Neurol., 60, 137-141 (2008).

13) Arai N., Sasahara A., Yoneyama T., Sekine C., Kikuchi A., Takahashi Y., Yokosako S., Yoshimura C., Ohbuchi H., Hirota K., Hagiwara S., Tani S., Kasuya H., Jpn. J. Stroke, 40, 243-248 (2018).
14) Hoshino H., Takagi M., Yamamoto Y., Ishibashi Y., Terayama Y., Takeda H., Tanahashi N., Adachi T., Taguchi Y., Takashima S., Tanaka K., Yasui K., Suzuki N., Jpn. J. Stroke, 33, 37-44 (2011).

15) Umemura T., Katsui K., Niimi Y., Umemura K., Terao S., Hirayama M., Jpn. J. Stroke, 30, 462-470 (2008).

16) Wang Y., Wang Y., Zhao X., Liu L., Wang D., Wang C., Wang C., Meng X., Cui L., Jia J., Dong Q., Xu A., Zeng J., Li Y., Wang Z., Xia H., Johnston C., CHANCE Investigators, N. Engl. J. Med., 369, 11-19 (2013).

17) Toyoda K., Uchiyama S., Yamaguchi T., Easton J. D., Kimura K., Hoshino H., Sakai N., Okada Y., Tanaka K., Origasa H., Naritomi H., Houkin K., Yamaguchi K., Isobe M., Minematsu K., CSPS.com Trial Investigators, Lancet Neurol., 18, 539-548 (2019). 